\title{
Organic Compounds in White River Water Used for Public Supply near Indianapolis, Indiana, 2002-05
}

Organic compounds studied in this U.S. Geological Survey assessment generally are man-made, including, in part, pesticides, solvents, gasoline hydrocarbons, personal-care and domestic-use products, disinfection by-products, and manufacturing additives. A total of 97 of 277 compounds were detected at least once among the 30 samples of source water collected approximately monthly during 2002-05 at the intake of the White River North treatment plant, one of several community water systems on the White River near Indianapolis, Indiana. The diversity of compounds detected indicated a variety of different practices (wastewater discharge, industrial, agricultural, domestic, and others) and pathways (treated-wastewater outfalls located upstream, overland runoff, and groundwater discharge) affecting the source-water supply. Eleven compounds were detected yearround in source-water samples, including atrazine, metolachlor, cis-1,2-dichloroethene, chloroform, other herbicides, and herbicide degradates commonly used in the White River Basin and in other agricultural basins across the United States. About two-thirds of the 46 compounds commonly detected in source water (in at least 20 percent of the samples) also were commonly detected in finished water (after treatment but before distribution). Although concentrations in source and finished water generally were below 0.1 microgram per liter, 37 compounds exceeded this threshold in at least 1 sample. About one-half of the detected compounds do not have human-health benchmarks or adequate toxicity information for evaluating results in a human-health context; however, two organic compounds-acetochlor and dieldrin-were detected in source-water samples at concentrations above human-health benchmarks. Additionally, atrazine was detected in source-and finished-water samples at concentrations above humanhealth benchmarks.

\section{Introduction}

The National Water-Quality Assessment (NAWQA) Program of the U.S. Geological Survey (USGS) characterized the occurrence of 277 organic compounds in source water (stream water collected before treatment) and finished water (treated water before distribution) from the White River North treatment plant, one of several community water systems that use the White River as its primary water supply (fig. 1). Samples were collected at least monthly during 2002-05 and included 30 source- and 13 finished-water samples. The samples were analyzed for pesticides and selected pesticide degradates (or "breakdown products), solvents, gasoline hydrocarbons, disinfection by-products, personal-care and domestic-use products, and other organic compounds.

Community water systems are required to monitor for compounds regulated under the Safe Drinking Water Act. Most of the compounds tested in this study are not regulated under U.S. Environmental Protection Agency (USEPA) federal drinking-water standards (U.S. Environmental Protection Agency, 2007a). The White River study is part of the ongoing Source Water-Quality Assessment (SWQA) investigation of community water systems that withdraw from rivers across the United States. More detailed information and references on the samplingdesign methodology, specific compounds monitored, and the national study are described by Carter and others (2007).

\section{Occurrence of Organic Compounds in Source Water}

About one-third of the 277 compounds were detected at least once in source-water samples. These compounds represent many different sources and uses and include herbicides, insecticides, fungicides, manufacturing additives, disinfection by-products, solvents, gasoline hydrocarbons, and personal-care products. Eleven compounds were detected year-round in source water, the majority of which are commonly used herbicides in the White River Basin.

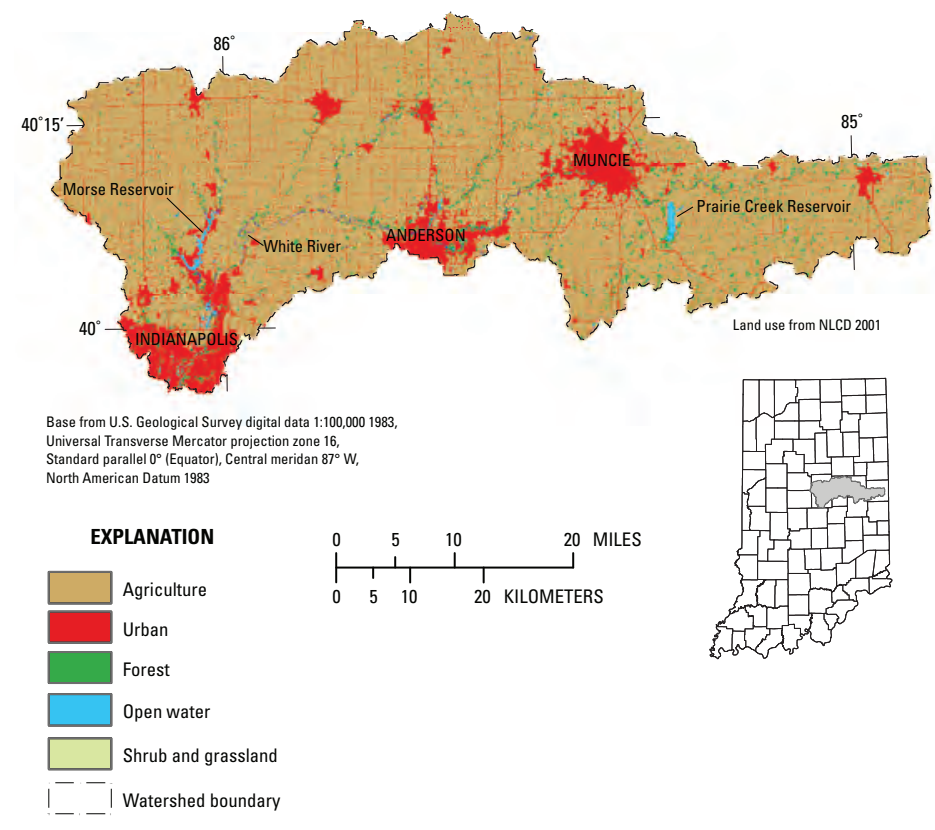

Figure 1. The White River Basin drains 1,164 square miles in central Indiana upstream of Indianapolis. Major land-use categories include agriculture (75 percent of the area), urban development ( 15 percent) and forest (5 percent). Streams and reservoirs in the White River Basin are the principal sources of drinking water. Approximately 86 thousand people use 15.8 million gallons of water per day from the White River North treatment plant (Dale Pershing, Indianapolis Water Company, written commun., 2010). 
Recent advances in laboratory analytical methods have led to detections of a wide variety of contaminants in the environment at lower concentrations than previously detectable (see inset). Ninetyseven of the 277 compounds tested were detected in at least 1 sourcewater sample from the White River; 180 compounds were not detected in any source-water sample (Carter and others, 2007; Kingsbury and others, 2008).

Forty-six compounds were detected in at least 20 percent of the source-water samples (defined in this study as "commonly detected;" table 1). Compounds commonly detected in source-water samples from the White River correspond to those previously detected in water-quality assessments of the watershed (Carter and others, 1995) and across the Nation (Gilliom and others, 2006).

Eleven compounds were detected year-round in more than 95 percent of source-water samples. The continuous occurrence may be attributed to groundwater discharge and (or) treated-wastewater discharge from municipalities located upstream (Kingsbury and others, 2008). Nine of the 11 compounds detected year-round were herbicides (atrazine, metolachlor, prometon, and simazine) or herbicide degradates (acetochlor ESA, metolachlor ESA, metolachlor OA, 2-hydroxyatrazine, and deethylatrazine (DIA)). Herbicides are used for weed control on row crops and in urban and residential areas in the White River Basin and across the Nation (Carter and others, 1995; Gilliom and others, 2006). The White River Basin, located in the corn-belt region of the Midwest and heavily used for row-crop agriculture, has some of the highest herbicide-application rates in the Nation (Gilliom and others, 2006). Correspondingly, the highest concentrations of atrazine from nine community water systems, sampled as part of the first phase of the SWQA study, were found in the White River Basin (Kingsbury and others, 2008). cis-1,2-Dichloroethene (a solvent) and chloroform (a disinfection by-product) also were detected in at least 95 percent of samples.

\section{Comparisons Between Source and Finished Water}

About two-thirds of the compounds commonly detected in source water also were commonly detected in finished water, and generally at similar concentrations.

Comparisons between source water and finished water are not intended to characterize treatment efficacy, but to provide a preliminary indication of the potential importance of compounds found in source water to the quality of finished water prior to distribution (see inset).

Thirty of the 46 compounds commonly detected in source water also were commonly detected in finished water, often at similar low concentrations (fig. 2). Seven herbicides and herbicide degradates (atrazine, 2-hydroxyatrazine, deethylatrazine, metolachlor, metolachlor ESA, metolachlor OA, and simazine), a solvent (cis-1,2,-dichloroethene), and a disinfection by-product (chloroform) were detected year-round in both source- and finished-water samples. Compounds commonly detected in source-water samples, but not in finished-water samples, likely were degraded or altered during water treatment as a result of transformation, volatilization, sorption, or sedimentation (Kingsbury and others, 2008).

Table 1. A total of 50 of the 277 organic compounds were detected in at least 20 percent of source water and (or) finished water samples.

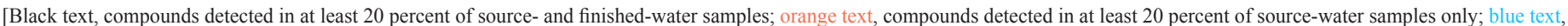

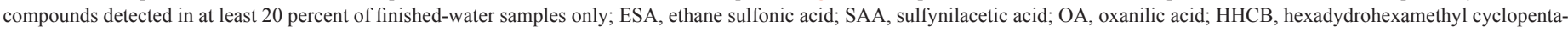
benzopyran]

\begin{tabular}{ll}
\hline \multicolumn{1}{c}{$\begin{array}{c}\text { Herbicides and } \\
\text { herbicide degradates }\end{array}$} & \\
\hline 2,4-D & Metolachlor ESA \\
2-Hydroxyatrazine & Metolachlor OA \\
3,4-Dichloroaniline & Metribuzin \\
Acetochlor & Prometon \\
Acetochlor ESA & Simazine \\
Acetochlor SAA & Terbuthylazine \\
Alachlor & Triclopyr \\
\cline { 2 - 2 } Alachlor ESA & \\
Alachlor OA & FYROL CEF (Tri(2-chloroethyl) phosphate) \\
Atrazine & FYROL PCF (Tri(dichloroisopropyl) phosphate) \\
Bentazon & Tri(2-butoxyethyl)phosphate \\
Chlorimuron-ethyl & \multicolumn{1}{c}{ Insecticides and insecticide degradates } \\
Deethylatrazine (DEA) & Carbaryl \\
Deisopropylatrazine (DIA) & Desulfinylfipronil \\
Dimethenamid & Diazinon \\
Dimethenamid ESA & Fipronil \\
Flumetsulam & \\
Imazaquin & Benomyl \\
Imazethapyr & Metalaxyl \\
Metolachlor &
\end{tabular}

\section{Disinfection by-products}

Bromodichloromethane
Bromoform
Chloroform

Dibromochloromethane

\begin{tabular}{l}
\hline \multicolumn{1}{c}{ Solvents } \\
\hline Carbon tetrachloride \\
cis-1,2-Dichloroethene \\
Perchloroethene (PCE) \\
Trichloroethene (TCE) \\
\hline \multicolumn{1}{c}{ Gasoline hydrocarbons and oxygenates } \\
Benzene \\
m- and p-Xylene \\
Toluene \\
\hline \multicolumn{1}{c}{ Personal-care and domestic-use products } \\
Acetyl-hexamethyl-tetrahydro-naphthalene (AHTN) \\
Caffeine \\
HHCB
\end{tabular}

Metolachlor 


\section{What "Detections" Might Mean to Human Health}

The analytical methods used in this study have detection levels often 100 to 1,000 times lower than Federal and State standards and guidelines for protecting water quality. Detections, therefore, do not necessarily indicate a concern to human health but rather assist in identifying the environmental presence of a wide variety of chemicals not commonly monitored in water resources and facilitate tracking changes in their occurrence and concentrations over time. These findings complement ongoing drinking-water monitoring of contaminants by water-supply facilities and regulated by USEPA in drinking water. Many compounds analyzed by the USGS are not included in other source-water and finished-water monitoring programs such as the Unregulated Contaminant Monitoring Program (U.S. Environmental Protection Agency, 2007b, c) and the U.S. Department of Agriculture's Pesticide Data Program (U.S. Department of Agriculture, 2008).

Typically, compounds present in finished-water samples were detected somewhat less frequently and at lower concentrations than in source-water samples; however, four compounds (bromoform, dibromochloromethane, carbon tetrachloride, and $m$ - and $p$-xylene) were commonly detected in finished water and not in source water. Higher detection frequencies and concentrations of disinfection by-products such as bromoform, dibromochloromethane, bromodichloromethane, and chloroform in finished-water samples is an expected outcome of the drinking-water disinfection process (Ivahnenko and Barbash, 2004; Ivahnenko and Zogorski, 2006). All paired samples collected at the White River North treatment plant exhibited higher detection frequencies and concentrations of disinfection by-products (often an order of magnitude greater) in finished-water samples than in source-water samples. Detection frequencies of carbon tetrachloride (a by-product of chemical plants and industrial activity) and $m$ - and $p$-xylene (a byproduct of petroleum and chemical factories) were only slightly higher than those found in source water.

\section{A Closer Look at Agricultural Herbicides and Degradates}

Detections and concentrations of commonly used herbicides and their degradates are similar in source water and finished water. The occurrence and concentrations of degradate compounds compared to their respective parent compounds varies by compound, as a result of differing chemical properties, use, and hydrologic pathways.
The herbicides atrazine and metolachlor and their respective degradates are highlighted here because of their frequent detection in this study as well as nationally. Both atrazine and metolachlor and their degradates (hydroxyatrazine, deethylatrazine, metolachlor ESA, and metolachlor OA) were detected in 100 percent of source- and finishedwater samples at the White River North treatment plant. Concentrations of herbicides often were lower in finished-water samples than in corresponding source-water samples (fig. 2). Concentrations of herbicide compounds were seasonally high during spring and early summer application periods, and highest concentrations were associated with runoff during this timeframe.

Summed concentrations of degradate compounds often are similar to or greater than parent herbicide concentrations. Source- and finished-water samples collected at the White River North treatment plant consistently showed that summed concentrations of metolachlor degradates were an order of magnitude greater than the parent concentration. Conversely, summed concentrations of atrazine degradates were less than concentrations of atrazine. Atrazine is chemically more stable, allowing it to persist longer in the hydrologic system than metolachlor, which tends to break down more quickly in the soil zone (Gilliom and others, 2006).

Transformation from parent herbicide to degradate compounds may result in conversion to less toxic compounds, but some degradates have toxicities that are similar to, or greater than, that of the parent pesticide (Gilliom and others, 2006). Therefore, understanding the occurrence of herbicide degradate compounds may be as important as characterizing the occurrence of the parent compound in sources of drinking water.
Figure 2. Thirty of the 46 compounds commonly detected in source water also were commonly detected in finished water, often at similar concentrations. Some compounds commonly detected in source water were removed or transformed and therefore were not detected in finished water (horizontal $\mathrm{x}$-axis). Other compounds were detected only in finished water (vertical y-axis).

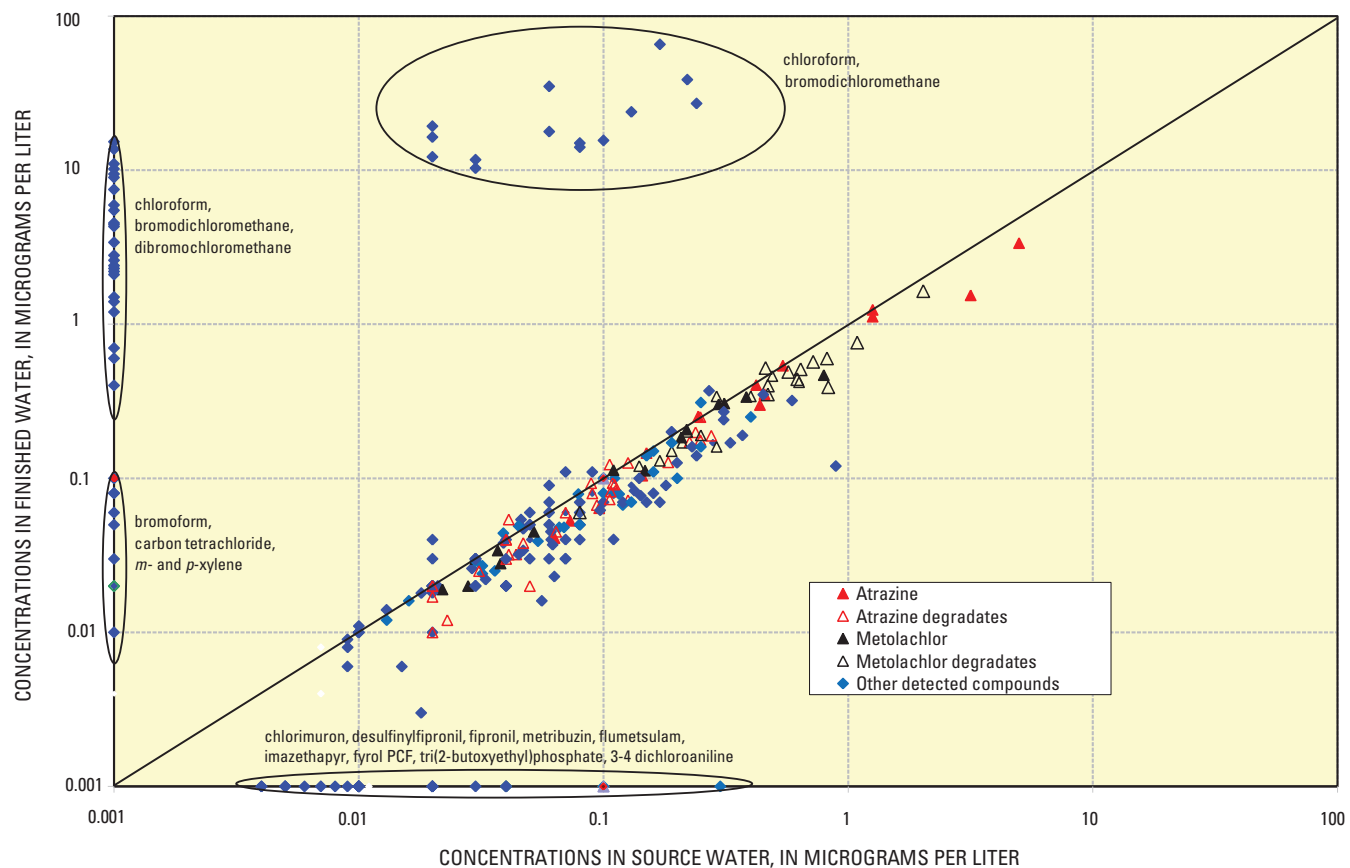




\section{Finished-Water Sampling, Water Treatment, and Magnitude of Comparisons to Source Water}

The White River North treatment plant uses conventional water treatment: coagulation using aluminum sulfate and a cationic polymer; flocculation and sedimentation; disinfection with chlorine; filtration; fluoridation and ammonia addition to form chloramines for the distribution system; chlorine or sodium permanganate are periodically used as a pre-oxidant; occasionally powdered activated carbon to remove organics and sodium hydroxide for $\mathrm{pH}$ adjustment; and intermittent blending with groundwater. The timing of finished-water samples was based on the treatment plant's production rate to account for the residence time of the source water in the treatment facility. Some differences between source-and finished-water quality might be attributable to changes in source-water quality that are not represented by the finished-water samples because of sample timing and variations in retention time and potential analytic variability associated with concentrations at or near laboratory reporting levels (Kingsbury and others, 2008). Some compounds detected in source water may have been transformed during the treatment process into compounds that were not monitored as part of this study.

The sampling design and resulting comparisons in this study are not intended to characterize treatment efficacy, but to provide a preliminary indication of the potential importance of compounds detected in source water to the quality of finished water before distribution. In general, conventional treatment was not specifically designed to remove most of the organic compounds monitored in this study.

\section{Results in a Human-Health Context}

Although concentrations in source and finished water generally were below 0.1 microgram per liter, 37 compounds exceeded this threshold in at least 1 sample. Three compounds were detected at concentrations greater than human-health benchmarks in at least one source-water sample; however, human-health benchmarks are only available for about one-half of the detected compounds. Human-health standards in the finished water are based on average annual concentrations and were not exceeded.

The type of conventional water treatment used by this community water system (typical of many systems across the Nation) is not specifically designed to remove most organic compounds found in the source water. However, concentrations found in the source water generally were less than 0.1 microgram per liter $(\mu \mathrm{g} / \mathrm{L})$. For perspective, reporting limits for public drinking water commonly are set through Federal regulations at $0.5 \mu \mathrm{g} / \mathrm{L}$, and water utilities generally are not required to measure below this limit.

Concentrations of 37 compounds that were commonly detected in source or finished water, or both (table 1), were greater than $0.1 \mu \mathrm{g} / \mathrm{L}$ in at least one sample (table 2). Human-health benchmarks are not available for 16 of the 37 compounds commonly detected with concentrations greater than $0.1 \mu \mathrm{g} / \mathrm{L}$.

Three compounds were detected at concentrations greater than human-health benchmarks in at least one sample - atrazine, acetochlor, and dieldrin. Although instantaneous high concentrations of contaminants in source water and finished water indicate the potential for temporarily elevated concentrations of contaminants in drinking water, they do not represent a violation of human-health standards, which are based on the average annual concentration. Atrazine was detected in 100 percent of source- and finished-water samples. During this 2-year study, atrazine was detected in five source-water samples and one finished-water sample at concentrations exceeding the USEPA MCL drinking-water standard, with maximum concentrations of 20.1 and $5 \mu \mathrm{g} / \mathrm{L}$, respectively, in source water during the first and second year of sampling. The average annual concentrations of atrazine in source water and finished water, 1.01 and $0.72 \mu \mathrm{g} / \mathrm{L}$, respectively, were below human-health benchmarks. Acetochlor was detected in nearly all source-water samples and approximately 70 percent of finishedwater samples; however, most detections of acetochlor were less than $0.1 \mu \mathrm{g} / \mathrm{L}$. Only one detection of acetochlor in source water exceeded the USGS HBSL for drinking water. Dieldrin is a bioaccumulative contaminant (moves up the food chain), which was banned by the USEPA in 1987 (U.S. Environmental Protection Agency, 2010). Dieldrin was detected at low concentrations in two source-water samples. In both samples, dieldrin exceeded the HBSL concentration of $0.002 \mu \mathrm{g} / \mathrm{L}$ (see inset). Dieldrin is not included in table 2 because it was not commonly detected.

\section{Human-Health Benchmarks Used in this Study}

Concentrations of regulated compounds were compared to USEPA maximum contaminant levels (MCLs), and concentrations of unregulated compounds that have USEPA-published toxicity information were compared to USGS health-based screening levels (HBSLs) (Toccalino and others, 2007). About one-half of detected compounds do not have human-health benchmarks for evaluating results in a humanhealth context. Human-health benchmarks are developed for individual compounds and not mixtures. The screening-level assessment provides an initial perspective on the potential importance of man-made organic compounds in source water; it is not a substitute for a comprehensive risk assessment, which includes many more factors, such as additional avenues of exposure.

Three compounds (simazine in source water and bromodichloromethane and chloroform in finished water) were detected at concentrations less than human-health benchmarks, but within a factor of 10 of the USEPA MCL or the USGS HBSL (table 2) in individual samples. While community water systems regularly monitor these compounds in the finished water, their detection in greater than 20 percent of source-water samples and at concentrations within a factor of 10 of human-health benchmarks may warrant their consideration in a low concentration, trends monitoring study. Human-health benchmarks are developed for individual compounds; however, mixtures of two or more compounds were present in most samples. The median number of compounds in source-water samples at the White River was 29. This result is similar to findings at comparable community water systems sampled as part of the SWQA study having a large amount of agricultural or urban land in the watershed (Kingsbury and others, 2008). The potential human-health effects of mixtures of co-occurring organic compounds are largely unknown and have not been extensively studied. Continued research is needed because human-health benchmarks are based on toxicity data for individual compounds, and the additive or synergistic effects of mixtures of compounds at low concentrations are not well understood (Gilliom and others, 2006).

\section{White River Findings in a National Context and Implications}

Several of the compounds detected in the White River (tables 1 and 2) are among the most commonly detected in ambient stream water and groundwater across the Nation (Gilliom and others, 2006; Zogorski and others, 2006). The occurrence and annual average concentrations of many compounds detected in source- and finished-water samples from the White River were considerably higher than those detected at 
Table 2. Thirty-seven compounds that were commonly detected in source and (or) finished water had concentrations greater than 0.1 micrograms per liter. One sample of atrazine had a concentration that exceeded human-health benchmarks in the finished water. Instantaneous high concentrations of atrazine in the finished water do not represent a violation of the standard, which is based on the average annual concentration.

$[\mu \mathrm{g} / \mathrm{L}$, microgram per liter; MCL, maximum contaminant level; HSBL, health-based screening level; ESA, ethane sulfonic acid; OA, oxanilic acid, SAA, sulfynilacetic acid; ---, no data; $\mathrm{ND}$, not detected]

\begin{tabular}{|c|c|c|c|c|c|c|c|c|}
\hline \multirow{2}{*}{ Name of compound } & \multicolumn{2}{|c|}{$\begin{array}{l}\text { Number of } \\
\text { samples }\end{array}$} & \multicolumn{2}{|c|}{$\begin{array}{c}\text { Percent } \\
\text { occurrence }\end{array}$} & \multirow{2}{*}{$\begin{array}{c}\text { Reporting } \\
\text { level } \\
\text { ( } \mu \mathrm{g} / \mathrm{L})\end{array}$} & \multirow{2}{*}{$\begin{array}{c}\text { MCL }^{1} \\
\text { or } \\
\text { HBSL } \\
(\mu \mathrm{g} / \mathrm{L})\end{array}$} & \multicolumn{2}{|c|}{$\begin{array}{c}\text { Maximum } \\
\text { concentration }(\mu \mathrm{g} / \mathrm{L})\end{array}$} \\
\hline & $\begin{array}{l}\text { Source } \\
\text { water }\end{array}$ & $\begin{array}{c}\text { Finished } \\
\text { water }\end{array}$ & $\begin{array}{l}\text { Source } \\
\text { water }\end{array}$ & $\begin{array}{l}\text { Finished } \\
\text { water }\end{array}$ & & & $\begin{array}{c}\text { Source } \\
\text { water }\end{array}$ & $\begin{array}{c}\text { Finished } \\
\text { water }\end{array}$ \\
\hline \multicolumn{9}{|c|}{ Disinfection by-products } \\
\hline Bromodichloromethane & 30 & 13 & 37 & 100 & 0.028 & 80 & 0.11 & 17.8 \\
\hline Bromoform & 29 & 12 & 0 & 83 & .5 & 80 & ND & .1 \\
\hline Chloroform & 30 & 13 & 90 & 100 & .024 & 80 & .3 & 65.6 \\
\hline Dibromochloromethane & 30 & 13 & 3 & 100 & .1 & 80 & .1 & 3.4 \\
\hline \multicolumn{9}{|c|}{ Fungicides } \\
\hline Metalaxyl & 28 & 13 & 21 & 23 & 0.01 & 600 & 0.12 & 0.02 \\
\hline \multicolumn{9}{|c|}{ Gasoline hydrocarbons } \\
\hline$m$ - and $p$-Xylene & 30 & 13 & 10 & 23 & 0.06 & 10,000 & 0.1 & 0.02 \\
\hline Toluene & 27 & 11 & 67 & 73 & .02 & 1,000 & .22 & .04 \\
\hline \multicolumn{9}{|c|}{ Herbicides and herbicide degradates } \\
\hline 2,4-D & 29 & 13 & 79 & 62 & 0.038 & 70 & 1.18 & 0.27 \\
\hline 2-Hydroxyatrazine (OIET) & 29 & 13 & 100 & 100 & .032 & 70 & 1.65 & .304 \\
\hline Aceotochlor SAA & 12 & 12 & 33 & 42 & .02 & --- & .28 & .17 \\
\hline Acetochlor & 29 & 13 & 93 & 69 & .006 & 1 & 4.32 & .14 \\
\hline Acetochlor ESA & 29 & 12 & 97 & 92 & .02 & --- & 1.42 & .31 \\
\hline Alachlor ESA & 29 & 12 & 93 & 92 & .02 & --- & .27 & .37 \\
\hline Alachlor OA & 29 & 12 & 93 & 92 & .02 & --- & .13 & .1 \\
\hline Atrazine & 29 & 13 & 100 & 100 & .007 & 3 & 20.1 & 3.36 \\
\hline Bentazon & 29 & 13 & 86 & 69 & .024 & 200 & .102 & .02 \\
\hline Chlorimuron-ethyl & 29 & 13 & 31 & 8 & .032 & 600 & .2 & .006 \\
\hline Deethylatrazine (DEA) & 30 & 13 & 100 & 100 & .014 & --- & .541 & .093 \\
\hline Deisopropylatrazine (DIA) & 29 & 13 & 83 & 77 & .08 & --- & .41 & .08 \\
\hline Dimethnamid & 12 & 12 & 25 & 8 & .02 & --- & .89 & .12 \\
\hline Dimethnamid ESA & 29 & 12 & 28 & 0 & .02 & --- & .11 & ND \\
\hline Imazaquin & 26 & 13 & 27 & 15 & .036 & 2,000 & .15 & .03 \\
\hline Imazethapyr & 29 & 13 & 31 & 0 & .038 & 2,000 & .13 & ND \\
\hline Metolachlor & 30 & 13 & 100 & 100 & .006 & 700 & 2.93 & .467 \\
\hline Metolachlor ESA & 29 & 12 & 100 & 100 & .02 & --- & 2.07 & 1.64 \\
\hline Metolachlor OA & 29 & 12 & 100 & 100 & .02 & --- & 1.47 & .46 \\
\hline Prometon & 30 & 13 & 97 & 38 & .01 & 400 & .19 & .2 \\
\hline Simazine & 29 & 13 & 100 & 100 & .005 & 4 & 2.3 & .1 \\
\hline Triclopyr & 29 & 13 & 31 & 23 & .026 & 400 & .45 & .35 \\
\hline \multicolumn{9}{|c|}{ Manufacturing additives } \\
\hline Fyrol cef (Tri(2-chloroethyl) phosphate) & 27 & 12 & 37 & 16 & 0.5 & --- & 0.1 & 0.1 \\
\hline Fyrol pcf (Tri(dichloroisopropyl) phosphate) & 25 & 11 & 36 & 9 & .5 & --- & .1 & .1 \\
\hline Tri(2-butoxyethyl)phosphate & 30 & 13 & 30 & 15 & .5 & --- & .3 & .1 \\
\hline \multicolumn{9}{|c|}{ Personal-care and domestic-use products } \\
\hline AHTN (Acetyl hexamethyl tetrahydronaphthalene) & 16 & 9 & 50 & 11 & 0.5 & --- & 0.12 & 0.097 \\
\hline Caffeine & 26 & 13 & 92 & 85 & .018 & --- & .2 & .126 \\
\hline HHCB (Hexahydrohexamethylcyclopentabenzopyran) & 26 & 10 & 92 & 70 & .5 & --- & .2 & .1 \\
\hline \multicolumn{9}{|c|}{ Solvents } \\
\hline cis-1,2-Dichloroethylene & 30 & 13 & 100 & 100 & 0.024 & 70 & 0.591 & 0.32 \\
\hline Perchloroethene (PCE) & 30 & 13 & 83 & 69 & .03 & 5 & .16 & .05 \\
\hline
\end{tabular}

${ }^{1} \mathrm{MCLs}$ are in bold text.

other community water systems sampled by the USGS SWQA of rivers that have upstream wastewater facilities and drain considerable agricultural and urban land (Kingsbury and others, 2008). Continued research of contaminant sources, transport mechanisms, trends, and fate in the environment is needed.
The USGS will continue to collaborate with and complement the work of other Federal, State, and local organizations to better understand and communicate the relevance of organic compounds detected in untreated source water and treated finished water and possible implications for human health and the environment. 
Future needs include the following:

- Increased emphasis on watershed management and source-water protection strategies to help minimize the sources and transport of compounds to source water and ultimately to finished water.

- Continued research to enhance toxicity information for commonly occurring unregulated compounds and mixtures that are commonly detected in source and finished water.

- Current and future monitoring and assessment to identify compounds not typically monitored in source water but commonly present in finished water, which may ultimately identify or lead to the development of treatment technologies for their removal.

\section{References Cited}

Carter, D.S., Lydy, M.J., and Crawford, C.G., 1995, Water-quality assessment of the White River Basin, Indiana-Analysis of available information on pesticides, 1972-92: U.S. Geological Survey Water-Resources Investigations Report 94-4024, accessed October 2010 at http://pubs.er.usgs.gov/usgspubs/wri/wri944024.

Carter, J.M., Delzer, G.C., Kingsbury, J.A., and Hopple, J.A., 2007, Concentration data for anthropogenic organic compounds in ground water, surface water, and finished water of selected community water systems in the United States, 2002-05: U.S. Geological Survey Data Series 268, 30 p., accessed October 2010 at http://pubs.usgs.gov/ds/2007/268.

Delzer, G.C., and Hamilton, P.A., 2007, National Water-Quality Assessment Program-Source Water-Quality Assessments: U.S. Geological Survey Fact Sheet 2007-3069, 2 p., accessed October 2010 at http://pubs.er.usgs. gov/usgspubs/fs/fs 20073069.

Gilliom, R.J., Barbash, J.E., Crawford, C.G., Hamilton, P.A., Martin, J.D., Nakagaki, Naomi, Nowell, L.H., Scott, J.C., Stackelberg, P.E., Thelin, G.P., and Wolock, D.M., 2006, The quality of our Nation's waters-Pesticides in the Nation's streams and ground water, 1992-2001: U.S. Geological Survey Circular 1291, 172 p., accessed October 2010 at http:// pubs.er.usgs.gov/usgspubs/cir/cir1291.

Ivahnenko, Tamara, and Barbash, J.E., 2004, Chloroform in the hydrologic system - Sources, transport, fate, occurrence, and effects on human health and aquatic organisms: U.S. Geological Survey Scientific Investigations Report 2004-5137, 34 p., accessed October 2010 at http://pubs.usgs.gov/sir/2004/5137/.

Ivahnenko, Tamara, and Zogorski, J.S., 2006, Sources and occurrence of chloroform and other trihalomethanes in drinking-water supply wells in the United States, 1986-2001: U.S. Geological Survey Scientific Investigations Report 2006-5015, 13 p., accessed October 2010 at http://pubs.usgs.gov/sir/2006/5015/.

Kingsbury, J.A., Delzer, G.C., and Hopple, J.A., 2008, Anthropogenic organic compounds in source water of nine community water systems that withdraw from streams, 2002-05: U.S. Geological Survey Scientific Investigations Report 2008-5208, 66 p., accessed October 2010 at http://pubs.usgs.gov/sir/2008/5208.

Toccalino, P.L., Norman, J.E., Booth, N.L., and Zogorski, J.S., 2007, Health-based screening levels-A tool for evaluating what waterquality data may mean to human health: U.S. Geological Survey, National Water-Quality Assessment Program, accessed April 15, 2008, at http://water.usgs.gov/nawqa/HBSL/.

U.S. Department of Agriculture, 2008, Agricultural Research Service (ARS), Pesticide properties database, accessed March 6, 2008, at http://www.ams.usda.gov/science/pdp/.

U.S. Environmental Protection Agency, 2007a, Setting standards for safe drinking water: U.S. Environmental Protection Agency, Office of Ground Water and Drinking Water, accessed June 1, 2007, at http://www.epa.gov/safewater/standard/setting.html.

\section{NAWOA Conducts SWQAs across the Nation}

Beginning in 2002, NAWQA initiated SWQAs at selected community water systems across the United States (Delzer and Hamilton, 2007). The long-term goal is to complete as many as 30 SWQAs at systems that withdraw water from streams by 2010 using standard protocols and nationally consistent methods (U.S. Geological Survey, 1997-2006)

This fact sheet highlights findings from the White River study, which is one of the first nine community water systems sampled. This fact sheet serves as a companion product to a USGS Data Series and a USGS Scientific Investigations Report that present findings for the nine systems across the United States (Carter and others, 2007; Kingsbury and others, 2008) (see http://water.usgs.gov/nawqa/swqa).

U.S. Environmental Protection Agency, 2007b, Unregulated Contaminant Monitoring Program, accessed January 4, 2007, at http://www.epa.gov/safewater/ucmr/index.html.

U.S. Environmental Protection Agency, 2007c, Unregulated Contaminant Monitoring Regulation (UCMR) for Public Water Systems-Revisions, Correction: Federal Register, January 26, 2007, v. 72, no. 17, p. 3,916.

U.S. Environmental Protection Agency, 2010, Persistent Bioaccumulative and Toxic (PBT) Chemical Program, Aldrin/Dieldrin, accessed July 1, 2010, at http://www.epa.gov/pbt/pubs/aldrin.htm.

U.S. Geological Survey, 1997-2006, National field manual for the collection of water-quality data: U.S. Geological Survey Techniques of Water-Resources Investigations, book 9, chaps. A1-A9, available at http://water.usgs.gov/owq/FieldManual/ (chapters were originally published during 1997-99; updates and revisions are ongoing and are summarized at http://water.usgs.gov/owq/FieldManual/ mastererata.html)

U.S. Geological Survey, 2007, NLCD 2001 Land Cover, accessed December 29, 2010, at http://geosemantics.umd.edu/socopdemo/ metadata/us_nlcd2001 30m dd83.htm.

Zogorski, J.S., Carter, J.M., Ivahnenko, Tamara, Lapham, W.W., Moran, M.J., Rowe, B.L., Squillace, P.J., and Toccalino, P.L., 2006, The quality of our Nation's waters - Volatile organic compounds in the Nation's ground water and drinking-water supply wells: U.S. Geological Survey Circular 1292, 101 p., accessed October 2010 at http://pubs.er.usgs.gov/ usgspubs/cir/cir1292.

\section{Written by Tim Lathrop and Dan Moran}

USGS promotes public access to water-quality information. This fact sheet, additional data and investigations reports, and other information are available on the World Wide Web at http://water.usgs. gov/nawqa/swqa. Included at this Web site are downloadable data on organic compound occurrence, information on sampling designs and methodology, background on data analyses, and frequently asked questions.

\section{For more information, contact:}

Tim Lathrop, U.S. Geological Survey, (317) 290-3333, ext. 182, trlathro@usgs.gov

Dan Moran, Veolia Water North America, (317) 917-4652,

dan.moran@veoliawaterna.com

Jeff Frey, U.S. Geological Survey, (317) 290-3333, ext. 151,

jwfrey@usgs.gov

Greg Delzer, U.S. Geological Survey, National Coordinator, (605)394-3320,gcdelzer@usgs.gov 